\title{
ANALYTICAL FINANCIAL PERFORMANCE OF NATIONALISED BANKS IN INDIA
}

\section{Dharmesh N. Rana}

\begin{abstract}
Banks play an important role in the economic development of every nation. They have control over a large part of the supply of money in circulation. A bank is a financial intermediary that accepts deposits and channels those deposits into lending activities. Banks are a fundamental component of the financial system, and are also active players in financial markets. Financial performance refers to the achievement of the bank in terms of profitability. The profitability of a bank denotes the efficiency with which a bank deploys its total resources to optimize its net profits and thus serve as an index to the degree of asset utilization and managerial effectiveness. In this article an attempt is made to see the financial performance of the selected nationalised banks with the different norms. They are grouped as follows, ratio analysis. For this study ten year nationalised Banks are selected. The Indian banking system faces several difficult challenges.
\end{abstract}

KEYWORDS: Analytical, Financial Performance Nationalised Bank.

\section{INTRODUCTION}

The origin of banking in India dates back to the Vedic period. There are repeated references in the Vedic literature to money lending which was quite common as a side business. Later, during the time of the Smritis, which followed the Vedic period, and the Epic age, banking became a full-time business and was diversified with bankers performing most of the functions of the present day banks. The Vaish community, who conducted banking business during this period, accepted deposits from the public, granted loans against pledges and 
personal security, granted simple open loans, acted as bailee for their customers, subscribed to public loans by granting loans to Kings, acted as treasurers and bankers to the state and managed the currency of the country.

\section{REVIEW OF LITERATURE}

Basu in his research study presented a picture of the dynamic role which the commercial banking system can play to help in the process of economic development in the country. The study underlined in detail the development of the commercial banking sector in the prenationalisation period and evaluated the diversified role the commercial banks have been called upon to play.

Nayan in his research study has made a comparison of the performance of individual nationalised banks with that of the banking system as a whole. An attempt was made to build up a model for the performance evaluation of the banks.

Yadav evaluated the working of Syndicate Bank in its northern zone and ascertained whether it was working on the lines suggested by the Government of India and the Reserve bank of India. With the help of an analytical and comparative study, the researcher has ascertained whether Syndicate Bank has been successful in the northern part of the country and how far it has been able to achieve the objectives of nationalisation by accelerating banking facilities in the rural, remote and the neglected areas.

Rastogi in his study evaluated 'The trends in India banking after nationalisation'. He made an effort to ascertain how the banks were in a position to cater to the banking needs of the Indian masses. He made an effort to suggest ways and means for further development of banking. The data for the study were collected from the Reserve bank of India and different other agencies directly or indirectly engaged in the task of developing banking facilities in the country. The reports of the various committees and study groups appointed by the Government of India and the Reserve Bank of India too were extensively used in the study. 


\section{RESEARCH METHODOLOGY}

Research is scientific and systematic search for pertinent information on a specific topic. A research design is a logical and systematic planning of a piece of research. In a present context, a research design includes:

1. Geographical Area

2. Population and Sample

3. Research Tools

4. Procedure for data collection

5. Methods and Tools of Analysis

This study is mainly based on the secondary data. The secondary data is extracted from the sources like Annual reports, consolidated profit and loss account and balance sheet, websites, and reports published by the banks.

\section{OBJECTIVES OF THE STUDY}

The basis objective of the present study is to analyze the past and present financial performance of the selected nationalized banks in India.

\section{However, the objectives are proposed in analytical study which is outlined as follows:}

To study the financial performance of selected nationalized banks.

$>$ To know the origin and growth of selected nationalized banks.

$>$ To analyze the overall efficiency, profitability, liquidity and leverage ratios for selected nationalized banks

To derive conclusion and suggest the measures for improving the financial position of the selected nationalized banks if necessary.

\section{HYPOTHESES}

\section{NULL HYPOTHESIS}

1. There is no significant difference between the management efficiency ratios of the selected nationalized banks. 
2. There is no significant difference between the profitability ratios of the selected nationalized banks.

\section{ALTERNATIVE HYPOTHESIS}

1. There is significant difference between the management efficiency ratios of the selected nationalized banks.

2. There is significant difference between the profitability ratios of the selected nationalized banks.

\section{LIMITATIONS OF THE STUDY}

$>$ This study is mainly based on secondary data from the published annual reports, website and literature.

$>$ The researcher has covered mainly 5 nationalised banks in India for the purpose of the research and selected variables are considered for financial performance of the banks.

$>$ There are many other different aspects to measure profitability and expert views are different from one another on this point.

\section{A. MANAGEMENT EFFICIENCY RATIOS}

\section{INTEREST INCOME TO TOTAL FUNDS RATIO}

Interest income to average working funds ratio expressed as a percentage, this ratio shows a bank's ability to leverage its average total resources in enhancing its main stream of operational interest income. The sum total of discount, interest from loans, advances and investment and from balance with RBI and other interest flows.

Formula: Interest Income to Total Fund Ratio $=\frac{\text { Interest Income }}{\text { Average working fund }} X 100$

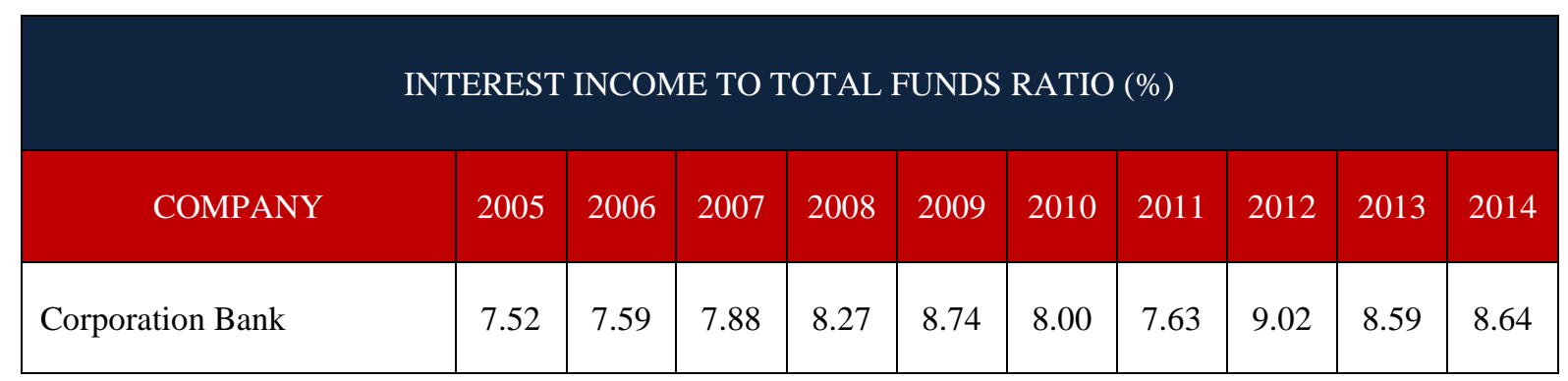


Towards Excellence: An Indexed, Refereed \& Peer Reviewed Journal of Higher Education /

Mr. Dharmesh Rana / Page 84-92

\begin{tabular}{|l|c|c|c|c|c|c|c|c|c|c|}
\hline Dena Bank & 8.15 & 6.89 & 7.66 & 8.34 & 8.44 & 8.17 & 8.18 & 8.87 & 8.87 & 8.37 \\
\hline Indian Bank & 8.36 & 8.02 & 8.46 & 8.81 & 9.37 & 9.31 & 9.01 & 9.68 & 9.17 & 8.71 \\
\hline Punjab National Bank & 8.52 & 7.23 & 7.88 & 8.86 & 9.89 & 9.07 & 8.01 & 8.71 & 8.96 & 8.40 \\
\hline State Bank of India & 8.41 & 7.94 & 8.27 & 8.82 & 8.88 & 8.52 & 7.15 & 8.32 & 8.25 & 8.12 \\
\hline
\end{tabular}

Table 1 - Interest Income to Total Fund Ratio

\section{INTERPRETATION}

From the above table-1 it can be concluded that on an average Indian bank has high ratio value of all time followed by Punjab National Bank and Canara Bank which indicates that Indian bank has highest ability to leverage its average total resources in enhancing its main stream of operational interest income whereas Bank of Baroda has lowest ability to leverage its average total resources in enhancing its main stream of operational interest income. During the year 2009 public banks have highest ability to leverage its total resources in enhancing its main stream of operational interest income while during year 2006 public bank have lowest ability to leverage its average total resources in enhancing its main stream of operational interest income. Based on the table-1 it can be seen that, in latest 5 years of study all banks have high average Interest income to total fund ratio compare to earlier 5 years of study.

\section{ASSET TURNOVER RATIO}

Asset turnover ratio is a financial ratio that measures the efficiency of a company's use of its assets in generating sales revenue or sales income to the company. Companies with low profit margins tend to have high asset turnover, while those with high profit margins have low asset turnover. Companies in the retail industry tend to have a very high turnover ratio due mainly to cutthroat and competitive pricing.

Formula: Asset Turnover Ratio $=\frac{\text { Revenue }}{\text { Assets }} \times 100$

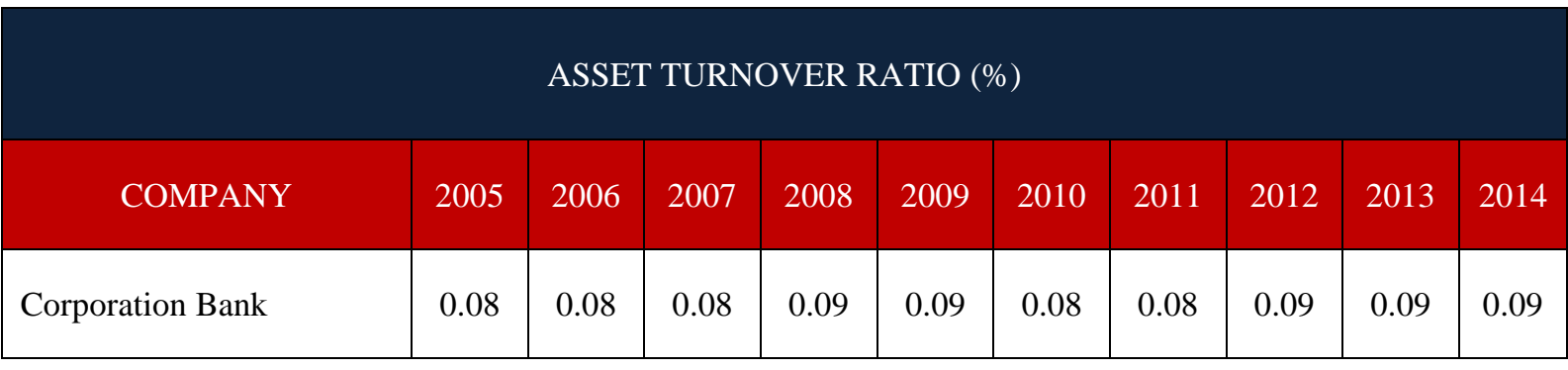


Towards Excellence: An Indexed, Refereed \& Peer Reviewed Journal of Higher Education /

Mr. Dharmesh Rana / Page 84-92

\begin{tabular}{|l|c|c|c|c|c|c|c|c|c|c|}
\hline Dena Bank & 0.09 & 0.07 & 0.08 & 0.09 & 0.09 & 0.05 & 0.08 & 0.09 & 0.09 & 0.09 \\
\hline Indian Bank & 0.09 & 0.08 & 0.09 & 0.09 & 0.10 & 0.10 & 0.09 & 0.10 & 0.09 & 0.09 \\
\hline Punjab National Bank & 0.09 & 0.08 & 0.08 & 0.09 & 0.11 & 0.10 & 0.08 & 0.09 & 0.09 & 0.09 \\
\hline State Bank of India & 0.10 & 0.09 & 0.09 & 0.10 & 0.10 & 0.09 & 0.08 & 0.09 & 0.09 & 0.09 \\
\hline
\end{tabular}

Table 2- Asset Turnover Ratio

\section{INTERPRETATION}

From the above table- 2 it can be concluded that on an average almost all banks have similar value of Assets turnover ratio. No major up and down has been observed during all 10 periods of study for all 10 banks taken under study. During year 2009 all banks have utilised their assets most efficient way to generate revenue whereas 2006, 2011 and 2007 banks have utilised their assets least efficient way. Based on the table- 2 it can be seen that, in latest 5 years and earlier 5 years of study all banks have utilised their assets most efficient way to generate revenue.

\section{B. PROFITABILITY RATIOS}

\section{NET PROFIT MARGIN RATIO}

This ratio is obtained by dividing net profit by Gross Income. It is valuable because it gives the overall profitability of business and shows the efficiency or otherwise of the business. Also this ratio looks at how much of a company's revenues are kept as net income.

Formula: Net Profit Margin Ratio $=\frac{\text { Net Profit }}{\text { Gross income }} \times 100$

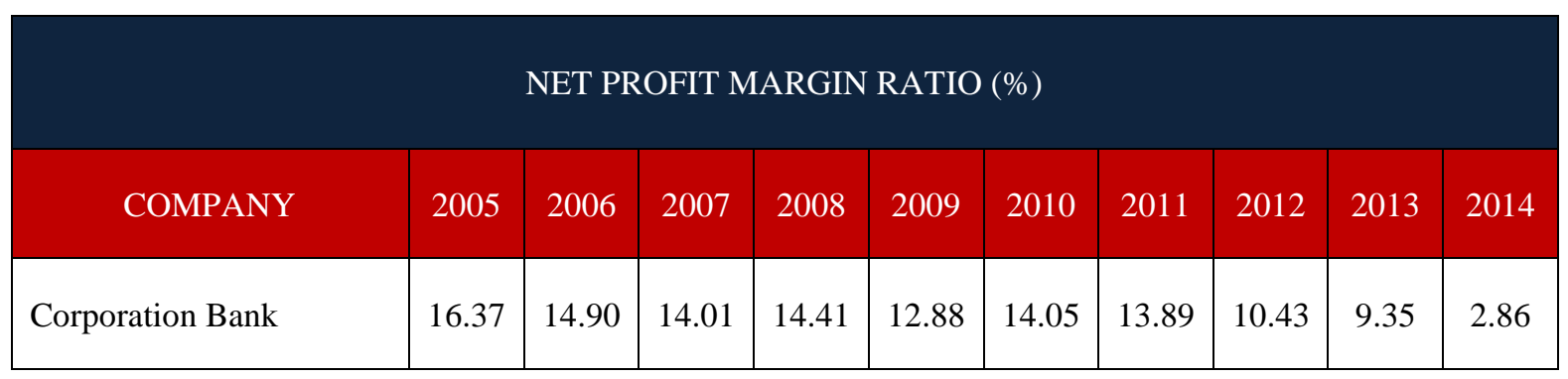


Towards Excellence: An Indexed, Refereed \& Peer Reviewed Journal of Higher Education /

Mr. Dharmesh Rana / Page 84-92

\begin{tabular}{|l|c|c|c|c|c|c|c|c|c|c|}
\hline Dena Bank & 3.11 & 3.85 & 8.30 & 11.61 & 10.95 & 11.17 & 12.15 & 10.88 & 8.48 & 5.06 \\
\hline Indian Bank & 12.36 & 13.40 & 15.45 & 16.52 & 16.25 & 17.03 & 18.31 & 14.28 & 11.38 & 6.97 \\
\hline Punjab National Bank & 13.84 & 14.50 & 12.53 & 12.68 & 13.76 & 15.64 & 14.48 & 12.02 & 11.33 & 6.99 \\
\hline State Bank of India & 11.56 & 11.21 & 10.12 & 11.65 & 12.03 & 10.54 & 7.58 & 9.68 & 10.39 & 7.03 \\
\hline
\end{tabular}

Table 3- Net profit margin ratio

\section{INTERPRETATION}

From the above table- 3 it can be concluded that with 14.20 average Net profit margin ratio Indian Bank stood at number one position followed by Bank of Baroda with 12.37 average ratio value. With 4.79 average Net profit margin ratio Central Bank of India stood at last position which indicates that Central Bank of India doing their business least efficient way. During year 2011 banks have highest average Net profit margin ratio value whereas during year 2014 banks have lowest average net profit margin ratio value. Based on the table-3 it can be seen that, in latest five years all banks have lower average Net profit Ratio values compare to earlier 5 years which indicates that in earlier 5 years of study period banks doing their business more efficient way than the current 5 years of study.

\section{RETURN ON ASSETS RATIO}

An indicator of how profitable a company is relative to its total assets excluding revaluation, In finance, a revaluation of fixed assets is a technique that may be required to accurately describe the true value of the capital goods a business owns. This should be distinguished from planned depreciation, where the recorded decline in value of an asset is tied to its age. Fixed assets are held by an enterprise for the purpose of producing goods or rendering services, as opposed to being held for resale in the normal course of business. For example, machines, buildings, patents or licenses can be fixed assets of a business.

Formula: Return on Asset Ratio $=\frac{\text { Net Income }}{\text { Total Assets }} \times 100$

\begin{tabular}{|l|c|c|c|c|c|c|c|c|c|c|}
\hline \multicolumn{1}{|c|}{ RETURN ON ASSETS RATIO (\%) } \\
\hline \multicolumn{1}{|c|}{ COMPANY } & 2005 & 2006 & 2007 & 2008 & 2009 & 2010 & 2011 & 2012 & 2013 & 2014 \\
\hline Corporation Bank & 212.98 & 235.28 & 262.51 & 294.79 & 341.36 & 402.60 & 481.85 & 558.70 & 625.56 & 601.95 \\
\hline Dena Bank & 34.61 & 37.15 & 43.24 & 54.62 & 67.95 & 83.43 & 103.76 & 122.59 & 164.66 & 132.81 \\
\hline
\end{tabular}


Towards Excellence: An Indexed, Refereed \& Peer Reviewed Journal of Higher Education /

Mr. Dharmesh Rana / Page 84-92

\begin{tabular}{|l|c|c|c|c|c|c|c|c|c|c|}
\hline Indian Bank & 4.11 & 30.49 & 74.95 & 106.93 & 127.52 & 154.66 & 184.44 & 214.94 & 242.89 & 248.16 \\
\hline $\begin{array}{l}\text { Punjab National } \\
\text { Bank }\end{array}$ & 248.93 & 287.79 & 321.65 & 341.98 & 416.74 & 514.77 & 632.48 & 777.39 & 924.45 & 991.39 \\
\hline State Bank of India & 457.39 & 525.25 & 594.69 & 776.48 & 912.73 & 1038.76 & 1023.40 & 1251.05 & 1445.60 & 1584.34 \\
\hline
\end{tabular}

Table 4- Return on assets ratio

\section{INTERPRETATION}

From the above table- 4 it can be concluded that State Bank of India has highest average Return on Assets ratio value compare to all banks taken under study which indicates that State Bank of India has utilised its assets most efficient way to generate profit. Bank of Maharashtra has lowest average Return on Assets ratio value compare to all banks taken under study which indicates that Bank of Maharashtra has utilised its assets least efficient way to generate profit. During year 2014 all banks have utilised their assets most efficient way to generate profit whereas during year 2005 banks have utilised their assets least efficient way to generate way to generate profit. Based on the table-4 it can be seen that, in latest five years all banks have higher average Return on Assets Ratio values compare to earlier 5 years which indicates that in latest 5 years of study period banks have utilised their assets more efficient way to generate profit.

\section{CONCLUSION}

Innovation with technology can add to bank's competitive edge in rendering services to its clients. If it is not possible to be the first in the market, the next best is to become a fast follower i.e. to quickly adapt to the new idea and operationalize it at the earliest. It is necessary to stay ahead, constantly upgrade the products and create new markets. Those who develop innovative methods to reduce cost and provide cheaper and quality service and products at reasonable prices will win. Overall it can be said that the banks also need to improve their product portfolio and must strive to be an one stop shop for the financial needs of middle and upper class income and high net worth individuals. This would be a good step to be a market leader in the highly competitive financial market. 


\section{REFERENCES}

$>$ Basu. C.R., The Role of the Commercial Banking in the Planned Economy of India, Ph.D Thesis, Burdwan University, Burdwan, 1977.

$>$ Nayan, Kamal, Performance Evaluation of Commercial Banks: Development of an Evaluation Model, Ph.D Thesis, Himachal Pradesh University, Simla, 1982.

$>$ Yadav, BalRam Singh, An Evaluation of the Working of the Syndicate Bank in Northern Zone. Ph.D Thesis, Rohilkhand University, Bareilly, 1983.

$>$ Rastogi, Peeyush Kumar, Post Nationlisation Trends in Indian Banking, Ph.D Thesis, Rohilkhand University, Barielly, 1982.

$>$ www.wikipedia.com

$>$ www.moneycontrol.com

$>$ www.corpbank.com

$>$ www.denabank.com

$>$ www.indianbank.in

$>$ www.pnbindia.com

$>$ www.sbi.co.in

Dharmesh N. Rana,

Research scholar, department of commerce, Vyakhyata sahayak, Gujarat arts and commeece college (evening) Ahmedabad Contact no. - 98240 72638, 9227572638 